\title{
Resource-restricted growth of eelgrass in New York estuaries: light limitation, and alleviation of nutrient stress by hard clams
}

\author{
John Carroll*, Christopher J. Gobler, Bradley J. Peterson
}

School of Marine and Atmospheric Sciences, Stony Brook University, 239 Montauk Hwy, Southampton, New York 11968, USA

\begin{abstract}
Globally, anthropogenic activities have degraded many estuarine habitat types, including seagrass meadows. The objective of this study was to identify the degree to which light and nutrients limit the productivity of eelgrass Zostera marina in Long Island estuaries (NY, USA) while concurrently assessing the ability of hard clams Mercenaria mercenaria to influence Z. marina growth and production. Field surveys were conducted to quantify the extent of eelgrass beds, along with environmental factors potentially constraining eelgrass growth. Experimental studies were conducted to determine the extent to which eelgrass is light- or nutrient-limited within the system, and to determine the capacity of hard clams to enhance eelgrass growth in situ. Eelgrass was found in only $14 \%$ of the sites sampled, but hard clams were found in $67 \%$ of sites with eelgrass. There was a strong longitudinal light gradient in Shinnecock Bay, with an extinction coefficient of 0.88 at the ocean inlet and 2.05 in the most remote regions. Pelagic light levels were inversely correlated with water column chlorophyll levels $(p=0.0027)$ and eelgrass productivity was strongly correlated with light levels ( $\mathrm{p}<0.0004)$, with both being maximal near the ocean inlet. In estuarine regions with high light levels but significantly lower sediment nitrogen $(\mathrm{N})$ content (near ocean inlet), hard clam or sediment nutrient additions yielded significantly higher eelgrass productivity and leaf $N$ content $(p<$ 0.001) compared to control plots. Combined with prior research, this study demonstrates that restoration of bivalves may benefit the expansion of eelgrass beds in shallow estuaries by relieving light and/or nutrient limitation.
\end{abstract}

KEY WORDS: Hard clams · Mercenaria mercenaria $\cdot$ Habitat amelioration · Positive interactions · Light stress $\cdot$ Eelgrass $\cdot$ Zostera marina

\section{INTRODUCTION}

Estuaries provide a variety of habitats for marine life including spawning and nursery grounds for many marine species. Much of the world's increasing population is now concentrated near coastlines and relies on estuaries for food, employment, shipping traffic, waste disposal, and recreation. As such, anthropogenic pressure on coastal ecosystems has increased significantly in recent decades, disrupting their ecology through eutrophication, overfishing, introduction of invasive species, and habitat alteration.

Seagrass is often a foundation species in estuarine systems offering a variety of ecosystem services which can strongly influence the structure, stability, and function of regions with dense meadows (Hemminga \& Duarte 2000). Some of these ecosystem services include the stabilization and oxygenation of the sediments through their root and rhizome complexes (Hemminga \& Duarte 2000), reduction of water flow as their blades act to dampen water movement (Newell \& Koch 2004), structural complexity which serves as a nursery ground for many species (Heck \& Wetstone 1977), a settlement site for juvenile bivalves (Bologna \& Heck 2000), and the contribution of detrital matter to estuarine food webs. Eelgrass Zostera marina is the dominant seagrass species in the northeastern USA (Green \& Short 2003) in general, and 
within Long Island (NY) waters in particular (Dennison et al. 1989).

Growth of autotrophs such as seagrass in marine systems is typically limited by nutrients or light. In systems with low nutrient loads and/or high water clarity, seagrass growth may be nutrient-limited. Low rates of estuarine nitrogen $(\mathrm{N})$ fixation, rapid phosphorus recycling, and phosphorus enrichment of waste water and/or river run-off often promote $\mathrm{N}$ limitation (Ryther \& Dunstan 1971), or limitation by a combination of both $\mathrm{N}$ and phosphorus (Hemminga \& Duarte 2000). However, anthropogenic nutrient loading in estuarine systems commonly encourages phytoplankton and macroalgal blooms which shade benthic habitats and cause light limitation of seagrass (Dennison et al. 1989, Valiela et al. 1997, Hauxwell et al. 2001, 2006). Natural and in situ experiments have demonstrated that shading, which can be exacerbated by anthropogenic processes, significantly reduces eelgrass distribution and survival (Hemminga \& Duarte 2000, Holmer \& Laursen 2002, Peralta et al. 2003). Although seagrass can adapt to lower light levels, significant and prolonged light reduction can eventually lead to a complete loss of seagrass biomass (Backman \& Barilotti 1976).

Filter-feeding bivalves may be capable of alleviating both light and nutrient limitation in seagrass. For example, eastern oysters Crassostrea virginica can effectively reduce suspended sediment concentrations (Newell \& Koch 2004) and chlorophyll concentrations (Newell et al. 2002). Recently, it has been demonstrated that the presence of filter-feeding bivalves (hard clams, eastern oysters, blue mussels) at naturally occurring densities can significantly reduce suspended algal biomass, increase light availability, and subsequently increase eelgrass growth rates (Wall et al. 2008). In addition, by depositing solid, nutrient-rich fecal material and pseudo-feces, bivalves mediate a flux of organic matter and nutrients out of the water column and into the sediments (Smaal \& Prins 1993). This nutrient enrichment of sediments can increase the growth of seagrass since seagrasses absorb the majority of their nutrients from the sediment through their roots (Peterson \& Heck 1999).

Reductions in bivalve populations, as well as anthropogenic impacts may have contributed to a decline in eelgrass in Long Island's south shore estuaries (LISSE). Eelgrass coverage decreased dramatically during the late 1980s with the annual occurrence of algal blooms, which decreased light levels reaching eelgrass beds (Dennison et al. 1989). Since that time, levels of suspended algal biomass have remained high (Suffolk County Department of Health Services, SCDHS 1976-2005), likely due in part to the low current abundances of hard clams and other filter feeders (Cerrato et al. 2004). As such, the majority of eelgrass beds in
LISSE currently subsist under subsaturating light (Cosper et al. 1987).

Losses of eelgrass beds in LISSE may also prohibit the recovery of commercially important bivalves on Long Island (bay scallop Argopecten irradians, hard clam Mercenaria mercenaria) which thrive within eelgrass habitats. Bay scallops have long been known to associate with seagrass species, and their survival has been demonstrated to be highest when attached to seagrass blades above the sediment surface (Ambrose et al. 1992). For hard clams, growth is often highest within dense seagrass beds due to lower predation rates by siphon nippers (Irlandi 1994, Irlandi \& Mehlich 1996) or enhanced food flux to the benthos caused by the slowing of water flow and subsequent sedimentation of particles (Irlandi \& Peterson 1991, Irlandi 1996) that allow clams to potentially reach predation threshold size faster. Hard clams have also been demonstrated to have higher survival in seagrass than in unvegetated sediments (Irlandi 1994) and had increasing survival with increasing seagrass cover (Irlandi 1997). As such, the dramatic declines and failed recoveries of scallop and hard clam fisheries in Long Island estuaries during the past 2 decades are likely due, at least in part, to concurrent loss of eelgrass habitats. However, seagrass persists in some regions of the LISSE and understanding the interplay between light stress and filter feeders may facilitate the restoration of both habitat and fisheries within the system.

Therefore, the objective of this study was to identify the degree to which light and nutrients limit the productivity of Zostera marina in LISSE while concurrently assessing the ability of Mercenaria mercenaria to influence $Z$. marina growth and production. To understand environmental factors constraining $Z$. marina populations in LISSE, we determined the spatial distribution of eelgrass and hard clams within 2 south shore estuaries and characterized the benthic and pelagic characteristics present along gradients of these populations. We concurrently conducted manipulative field experiments to assess the degree to which a naturally occurring light gradient influenced $Z$. marina productivity and to determine the ability of hard clams to facilitate eelgrass growth through sediment nutrient enrichment.

\section{MATERIALS AND METHODS}

Study site. This study was executed in 2 bays in the LISSE, namely Shinnecock Bay and Quantuck Bay (Fig. 1A). The LISSE is a series of barrier island estuaries stretching $145 \mathrm{~km}$ from Coney Island, New York City, east to Southampton. Shinnecock Bay is the easternmost bay in the system, approximately $15 \mathrm{~km}$ long, 


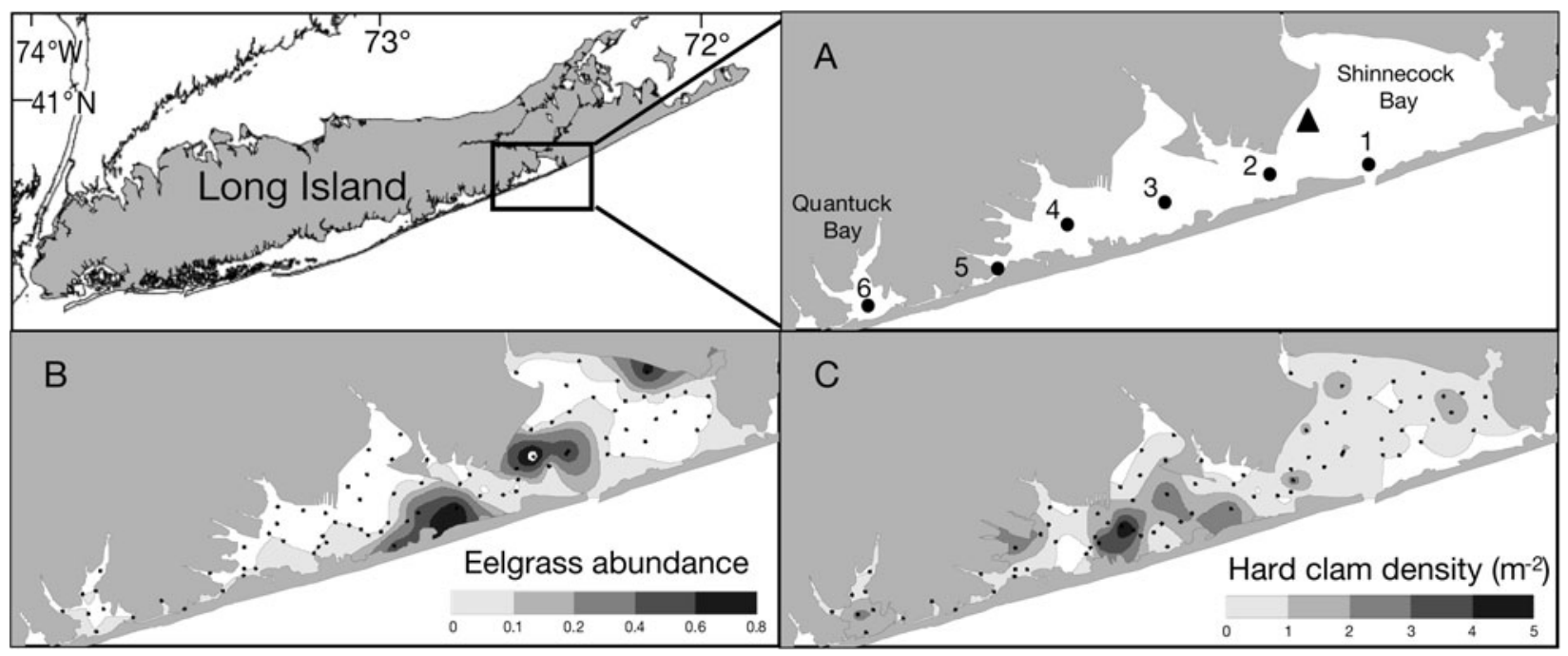

Fig. 1. (A) The study sites in Shinnecock Bay and Quantuck Bay, Long Island, New York. Permanent stations are represented by black circles with site nos. 1 to 6 . The black triangle shows the location of the shading experiment. (B) Eelgrass abundance as mean percentage cover in 10 quadrats at each random station (dots). (C) Hard clam density (ind. $\mathrm{m}^{-2}$ )

with an area of $\sim 40 \mathrm{~km}^{2}$ and a mean depth between 2 and $3 \mathrm{~m}$. It is connected to Quantuck Bay in the west via a $2.5 \mathrm{~km}$ long canal. Quantuck Bay is much smaller, approximately $1.5 \mathrm{~km}$ from east to west, with an area of $\sim 2.5 \mathrm{~km}^{2}$ and an average depth of $\sim 2 \mathrm{~m}$. Shinnecock Bay tidally exchanges with the Atlantic Ocean through the Shinnecock Inlet ( $40^{\circ} 50.52^{\prime} \mathrm{N}, 72^{\circ} 28.70^{\prime} \mathrm{W}$ ). Quantuck Bay is flushed to the east and west via narrow canals. The mean tidal range is approximately $0.5 \mathrm{~m}$ for this system. For more detailed information on physical and hydrodynamic characteristics of a typical LISSE embayment see Wilson et al. (1991).

Field survey. All surveys were conducted during the summer when eelgrass productivity was expected to be highest. A stratified random sampling design was used to identify 81 sites throughout the study area (Fig. 1A). At each site, ten $0.25 \mathrm{~m}^{2}$ quadrats were randomly placed on the sediment surface and a visual assessment of the benthic plant community was conducted. Both submerged aquatic vegetation (SAV) and macroalgal cover were scored using a modified BraunBlanquet scoring technique (Braun-Blanquet 1972, Fourqurean et al. 2001). Benthic cover was defined as the fraction of the total quadrat area that was obscured by a particular plant taxon when viewed from directly above. From the raw observations of species cover in each quadrat at a site, a single density estimate was calculated for each plant taxon encountered in the quadrats. Density was calculated as:

$$
D_{i}=\Sigma S_{i j} / \mathrm{N}
$$

where $D_{i}=$ density of taxon $i_{i} j=$ quadrat number from 1 to $N$, the total number of quadrats sampled at a site; and $S_{i j}=$ the Braun-Blanquet score for taxon $i$ in quadrat $j$.

For any taxon, $D$ can range from 0 and 5, the latter being the maximum Braun-Blanquet score. A score of 0 indicates the taxon was absent from the quadrat, 1 is less than $5 \%$ cover, 2 is 5 to $25 \%$ cover, 3 is 25 to $50 \%$, 4 is 50 to $75 \%$, and 5 is 75 to $100 \%$ cover. After surveying benthic plants, all hard clams within each quadrat were removed, quantified and returned to the laboratory, where soft tissue was removed, dried to constant mass at $70^{\circ} \mathrm{C}$ and the weight recorded.

A PVC core (5 $\mathrm{cm}$ diameter; $15 \mathrm{~cm}$ depth) was used to collect the upper $5 \mathrm{~cm}$ of sediment for the determination of organic matter content. Samples were dried to constant mass at $70^{\circ} \mathrm{C}$, then combusted at $500^{\circ} \mathrm{C}$ for $5 \mathrm{~h}$ to burn off organic matter. Organic matter content (as \% dry weight) of the sediments was determined as the constituent lost on ignition and calculated as [(dry wt - ashed wt)/dry wt] $\times 100$.

In addition, 2 smaller syringe cores $\left(5 \mathrm{~cm}^{3}\right)$ were used to collect the upper $2 \mathrm{~cm}$ of surface sediment for the assessment of benthic chlorophyll a (chl a) concentrations, porosity and sediment carbon (C) and nitrogen (N) concentrations. Benthic chl a concentrations were regarded as a surrogate indicator of light reaching the sediment surface. To measure benthic chl $a$, a known volume of sediment was immersed in $20 \mathrm{ml}$ of acetone, shaken and extracted at $-20^{\circ} \mathrm{C}$ for $24 \mathrm{~h}$ prior to fluorometric analysis (Parsons et al. 1984). The second small core was used to determine sediment porosity and sediment nutrient concentrations. Porosity was calculated using the following equation: 


$$
\text { Porosity }=(f W \times d S) /[f W \times d S+(1-f W) \times d W]
$$

where $\mathrm{fW}$ is the weight fraction of water, $\mathrm{dS}$ is the density of the sediment particles $\left(\sim 2.6 \mathrm{~g} \mathrm{~cm}^{-3}\right)$, and dW is the density of seawater $\left(1.02 \mathrm{~g} \mathrm{~cm}^{-3}\right)$ (Berner 1971).

After determining porosity, samples were homogenized to a fine powder and the elemental contents of $\mathrm{C}$ and $\mathrm{N}$ were determined by oxidation in a CE Instruments Flash EA 1112 Elemental Analyzer (Atkinson \& Smith 1983).

Once the field surveys were completed, point data generated on sediment characteristics, densities of SAV and hard clams were used to produce continuous maps of these parameters across Shinnecock and Quantuck Bays using the spatial analysis program Arc GIS. A kriging algorithm (Watson 1992) was used to interpolate between the random point data, and areas of coverage and density from these interpolated surfaces were computed. Since species density data are rarely normally distributed, correlations between densities of different species, between species densities and environmental parameters, and between different environmental parameters were tested using the nonparametric Spearman's $\rho$. Significance of correlations was assessed using 2-tailed tests. To assess the differences between survey sites with and without eelgrass, and with and without hard clams, a 2-tailed, paired sample $t$-test was used.

Eelgrass productivity along a natural light gradient. We conducted a field experiment to examine how in situ light concentrations altered Zostera marina productivity by placing eelgrass at 6 locations in $2 \mathrm{~m}$ of water along a natural light gradient from Shinnecock Inlet to Quantuck Bay (Fig. 1A). Eelgrass shoots were harvested from a lush meadow in Shinnecock Bay, and a hole was punched at the base of shoots with an 18gauge needle, following a modified leaf marking method (Zieman 1974). Within $2 \mathrm{~h}$ of the initial harvest, shoots were transplanted into plastic planter's pots with $1 \mathrm{~mm}$ sieved, low organic matter content ocean beach sand. The pots were randomly assigned to weighted wire racks and placed at each experimental site. One shoot was planted in each pot, for a total of 16 plants at each site. The experimental pots were retrieved after $14 \mathrm{~d}$ and productivity was assessed.

Along the same gradient, pelagic water quality was evaluated weekly. Light was measured using a Li-Cor LI-193 spherical underwater quantum sensor, and the light attenuation coefficient, $K_{d}$, was calculated from incoming irradiance and light measured at $1 \mathrm{~m}$ depth using the following formula:

$$
K_{d}=-\ln \left(I_{z} / I_{0}\right) / z
$$

where $K_{d}$ is the light attenuation coefficient, $I_{z}$ is the irradiance at depth $z$ (always measured at $1 \mathrm{~m}$ below the surface), and $I_{0}$ is the irradiance at the surface.

Secchi depth measurements were also made. Although the sites were of equal mean depth, the actual depth and Secchi depth could vary according to the stage in the tidal cycle during which the measurements were recorded. Thus, Secchi depth was converted to a percentage of the water column for comparison among sites. Chl a was measured by filtering surface water samples onto either replicated GF/F filters or $2 \mu \mathrm{m}$ or $5 \mu \mathrm{m}$ polycarbonate filters, followed by freezing and extracting in acetone. Fluorescence was measured with a Turner fluorometer (Parsons et al. 1984). This procedure allowed the amount of chl $a$ in the $>5,2$ to 5 and $<2 \mu \mathrm{m}$ size fractions to be determined, since small particles tend to scatter light more than larger particles (Morel 1987).

After data were collected, differences in productivity, light levels, and chl a between the sites were compared by ANOVA. Correlations between eelgrass productivity and light, productivity and chl $a$, and chl $a$ and light were conducted using Spearman's $\rho$, and significance of the correlations was assessed using a 2-tailed test.

Shading vs. fertilization experiment. In addition to the field survey, a manipulative field experiment was conducted in an eelgrass meadow with low sediment $\mathrm{N}$ levels in eastern Shinnecock Bay to assess the ability of hard clams to alleviate nutrient stress. A $2 \times 3$ factorial randomized design was used for this experiment which consisted of 2 factors: light availability and nutrient enrichment. Light availability had 2 levels - shaded and non-shaded-while nutrient availability had 3 levels - an unamended control, 1 hard clam (and its associated biodeposits), and 1 fertilizer stake $0.0625 \mathrm{~m}^{-2}(\mathrm{n}=10$ plots for each nutrient treatment). The shaded treatments consisted of a $\operatorname{Vexar}^{\mathrm{TM}}$ mesh $(7 \times 7 \mathrm{~mm})$ suspended above the grass, reducing ambient light reaching the grass below by $40 \%$ (as determined with a Li-Cor LI-193 spherical underwater quantum sensor; $\mathrm{n}=30$ each for ambient and shaded plots.

The margins of all experimental plots $\left(0.0625 \mathrm{~m}^{2}\right)$ were marked by anchoring PVC frames to the sediment. Possible translocation of stored nutrients through the seagrass rhizomes out of or into the plots was prevented by severing the rhizomes around the perimeter of each plot. Each light treatment (ambient and shaded) was randomly assigned 10 plots for hard clam additions. One individual $(\sim 5 \mathrm{~cm}$ valve length) was added to the center of each plot. This yielded a clam density of $16 \mathrm{~m}^{-2}$, which is higher than current clam densities in LISSE, but considerably lower than historical densities (Cerrato et al. 2004). Another 10 plots were randomly assigned to the fertilized treat- 
ments and received a single Miracle-Gro ${ }^{\circledR}$ Tree \& Shrub Fertilizer spike to the center. The fertilizer spike dry mass was approximately $115 \mathrm{~g}$, with $15 \%$ ammonia-N, $5 \%$ phosphorus $\left(\mathrm{P}_{2} \mathrm{O}_{5}\right)$, and $10 \%$ soluble potash $\left(\mathrm{K}_{2} \mathrm{O}\right)$. The fertilizer spikes were totally dissolved over the course of the $35 \mathrm{~d}$ experiment (8 June to 13 July 2005). The remaining 10 plots in each light treatment served as controls.

Treatment effects on eelgrass short shoot leaf number, leaf morphometrics, leaf productivity and leaf tissue nutrient content were compared at the conclusion of the experiment. Leaf production was measured by using the modified leaf marking method of Zieman (1974). Fourteen days prior to the conclusion of the experiment, all shoots within the plots were marked. On conclusion of the experiment, all shoots were harvested. In the laboratory, the number of leaves, leaf width, leaf length, and daily gross above-ground production were determined from the harvested shoots. The leaves were dried to a constant mass at $70^{\circ} \mathrm{C}$ and homogenized by milling to a fine powder. Total $\mathrm{C}$ and $\mathrm{N}$ content of the seagrass samples was determined for each site as described above for the sediment analyses of $\mathrm{C}$ and N. Since leaf tissue nutrients respond to differences in sediment pore water nutrients (Fourqurean et al. 1992), a significant change in these values was used as a proxy for changes in sediment nutrient concentrations.

A 2-way ANOVA was used to test for significant differences and interactions between light shading and nutrient enrichment. A balanced ANOVA design (i.e. equal $\mathrm{n}_{\mathrm{i}}$ ) was employed, ensuring statistical robustness with respect to assumptions of homoscedasticity and normality (Zar 1996). Prior to any statistical analysis, ratio data was arcsine-transformed. When either factor had a significant effect on the response variable and no interaction occurred, multiple comparison tests (Tukey's Studentized range) were used to test for significant differences between levels within the treatment. Results of the statistical tests were considered to be significant if $\mathrm{p}<0.05$.

\section{RESULTS}

\section{Field survey}

Eelgrass was present at 11 (equalling $14 \%$ ) of the 81 sites surveyed. Very little eelgrass was found along the north end and western extent of Shinnecock Bay, and the highest concentrations of eelgrass were found across from the inlet and along the shallow south shore just to the west of the inlet (Fig. 1B). The mean standing crop for the eelgrass collection sites was 74.8 $( \pm 25.2 \mathrm{SD}) \mathrm{g}$ dry wt $\mathrm{m}^{-2}$. Hard clams Mercenaria mer- cenaria were collected at $55(68 \%)$ of the 81 sites. While ubiquitous throughout the bay, the greatest densities of hard clams were found in or adjacent to eelgrass beds, where densities reached a maximum of $5.2 \mathrm{~m}^{-2}$ (Fig. 1C). The mean density of clams for the study area was $0.82 \pm 0.12 \mathrm{~m}^{-2}$, while the mean clam biomass at the individual sites with clams was $5.12 \pm$ $0.83 \mathrm{~g}$ dry wt $\mathrm{m}^{-2}$. Hard clams were found in $67 \%$ of the sites with eelgrass, but in only $33 \%$ of non-eelgrass sites. Further, hard clam densities were almost double in eelgrass sites $\left(1.07 \pm 0.32 \mathrm{~m}^{-2}\right)$, compared to noneelgrass sites $\left(0.62 \pm 0.13 \mathrm{~m}^{-2}\right)$.

Sediment characteristics varied greatly across the estuary and were strongly correlated with each other. Sediment N content was positively correlated with organic matter content $\left(\mathrm{p}<0.001, \mathrm{r}^{2}=0.91\right)$, porosity $\left(\mathrm{p}<0.001, \mathrm{r}^{2}=0.88\right)$ and $\mathrm{C}$ content $\left(\mathrm{p}<0.001, \mathrm{r}^{2}=0.93\right)$, but negatively correlated with benthic chl a $(\mathrm{p}<0.001$, $r^{2}=-0.62$ ) (Fig. 2). There was no correlation between the presence of hard clams and sediment characteristics, perhaps due to low overall abundances of hard clams, which were a fraction of those found in this system decades ago (Cerrato et al. 2004).

Sediment characteristics within the eelgrass beds were significantly different from those outside. Organic matter content of the sediments within eelgrass sites was significantly lower than outside eelgrass sites $(1.32 \pm 0.27$ vs. $5.42 \pm 0.50 \%, p<0.001)$. Similarly, values for sediment $C$ content $(0.54 \pm 0.11$ vs. $1.94 \pm$ $0.17 \%, \mathrm{p}=0.001)$, sediment $\mathrm{N}$ content $(0.054 \pm 0.013$ vs. $0.22 \pm 0.02 \%, p=0.002)$, and porosity $(0.515 \pm 0.091$ vs. $0.684 \pm 0.178, p=0.007$ ) were also significantly lower within eelgrass sites compared to outside. In contrast, benthic chl a was higher in eelgrass sites $\left(116 \pm 10 \mu \mathrm{g} \mathrm{cm}^{-2}\right)$ than in non-eelgrass sites $(97 \pm$ $6.9 \mu \mathrm{g} \mathrm{cm}^{-2}$ ), although this difference was not significant.

\section{Eelgrass productivity along a natural light gradient}

A strong gradient in chl $a$, light penetration, and eelgrass productivity was present along the east-west axis of Shinnecock and Quantuck Bays. Throughout the study, light penetration was highest at the Shinnecock inlet and decreased moving west toward Quantuck Bay. The extinction coefficient, $K_{d}$, increased from $0.88 \pm 0.12$ at the ocean inlet to $2.05 \pm 1.19$ at stations furthest west (Stn 6, Fig. 3A). Similarly, Secchi depths represented $100 \%$ of the water column at site 1 and decreased gradually at stations moving west to Stn 6, where the Secchi depth represented only $58 \pm 10 \%$ of the water column (Fig. 4).

The observed light gradient was likely caused by differing concentrations of phytoplankton biomass, which 


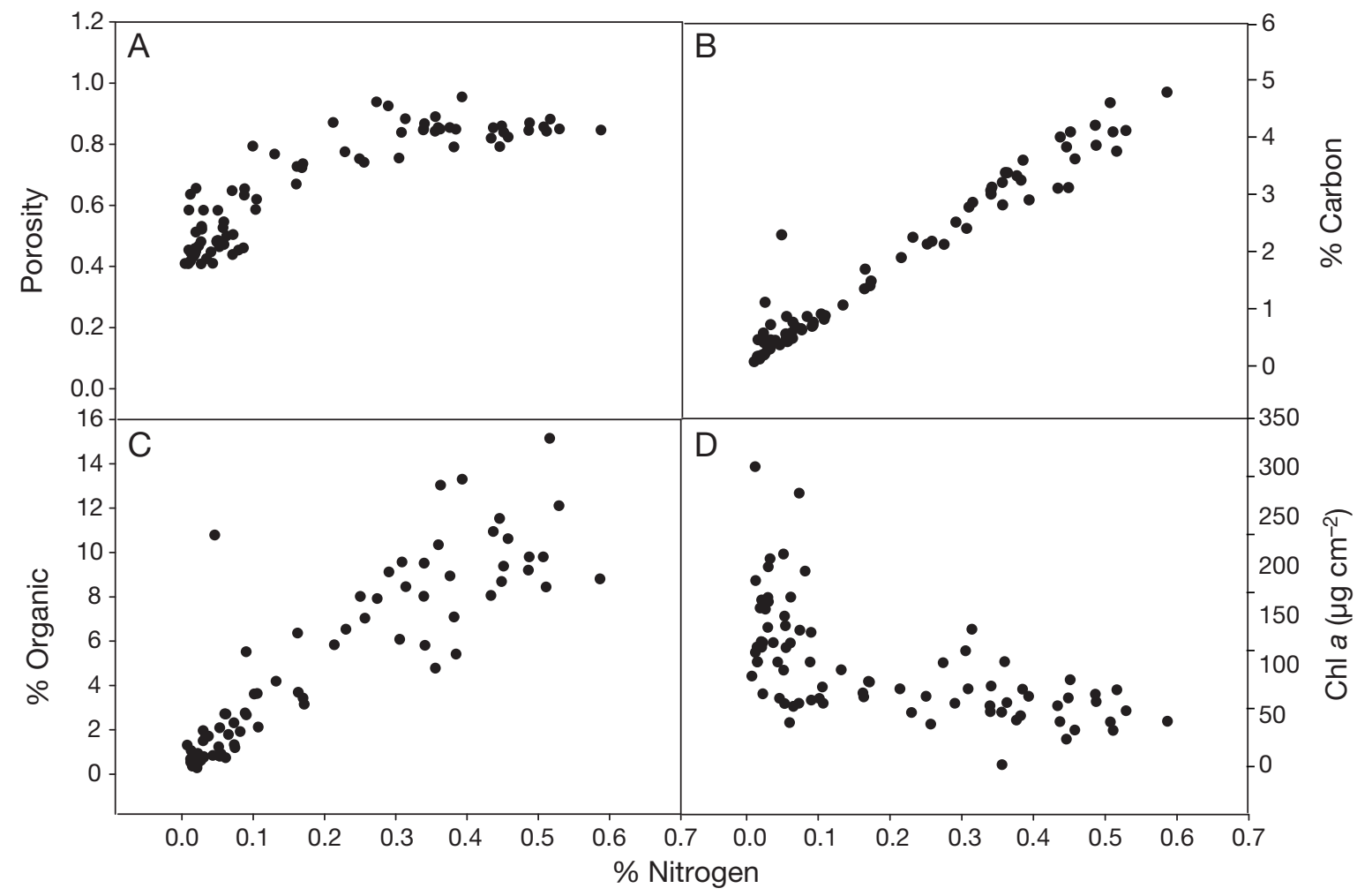

Fig. 2. Sediment characteristics plotted against sediment nitrogen content (\%): (A) porosity, (B) carbon content, (C) organic matter content $\left(\%\right.$ dry weight), and (D) chl $a$. All relationships were significant $(p<0.001)$, with $\mathrm{r}^{2}$ of $0.875,0.926,0.909$, and -0.622 for porosity, carbon content, sediment total organic content, and chl $a$, respectively

also displayed a strong east-west gradient through Shinnecock Bay. The inlet station consistently had lower levels of total chl $a$ and less chl $a$ in the smaller size fractions when compared to the other sites. Mean total chl $a$ at the inlet was $0.83 \pm 0.20 \mu g \mathrm{l}^{-1}$, with a size distribution of $0.13 \pm 0.09 \mu \mathrm{g} \mathrm{l}^{-1}$ at $>5 \mu \mathrm{m}, 0.12 \pm 0.06 \mu \mathrm{g}$ $\mathrm{l}^{-1}$ at 2 to $5 \mu \mathrm{m}$, and $0.72 \pm 0.42 \mu \mathrm{g} \mathrm{l}^{-1}$ at $<2 \mu \mathrm{m}$. Moving west, levels of all size fractions steadily increased towards Quantuck Bay, where total chl a concentrations were $17.5 \pm 6.47 \mathrm{\mu g} \mathrm{l}^{-1}$, divided into $3.57 \pm 1.28 \mu \mathrm{g}$ $\mathrm{l}^{-1}$ at $>5 \mu \mathrm{m}, 8.19 \pm 4.34 \mu \mathrm{g} \mathrm{l}^{-1}$ at 2 to $5 \mu \mathrm{m}$, and $4.53 \pm$ $1.34 \mu \mathrm{g} \mathrm{l}^{-1}$ at $<2 \mu \mathrm{m}$ (Fig. 3B).

Fig. 3. (A) Extinction coefficient, $K_{d}$ (mean $\left.\pm \mathrm{SE}\right)$, plotted along a natural light gradient from an ocean inlet station (Stn 1), to the most distant station (Stn 6). High values for $K_{d}$ mean higher attenuation and less light. (B) Water column chl $a\left(\mu g \mathrm{l}^{-1}\right)$ and eelgrass productivity $\left(\mathrm{cm}^{2} \mathrm{ss}^{-1} \mathrm{~d}^{-1}\right)$ plotted along the natural light gradient from Stn 1 to Stn 6 . Chl $a$ is represented by the stacked vertical bars; relative SD for all chl measurements was \pm 1.02 . Productivity at Stn 1 was significantly higher $(p=0.004)$ than at $S t n 6$. Eelgrass productivity was significantly influenced by the whole phytoplankton community $(p=0.001)$, and by all size fractions $(>5 \mu \mathrm{m}$, $\mathrm{p}=0.015 ; 2$ to $5 \mu \mathrm{m}, \mathrm{p}=0.045 ;$ and $<2 \mu \mathrm{m}, \mathrm{p}=0.006$ ) ss: short shoot
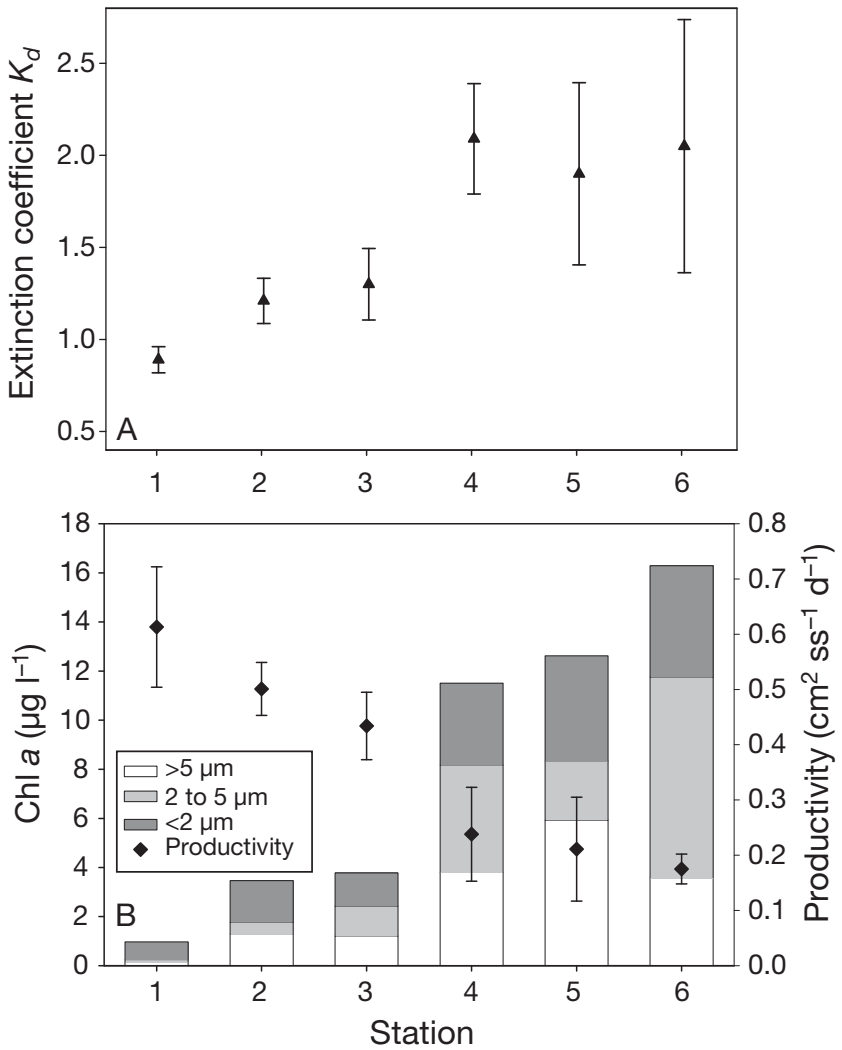


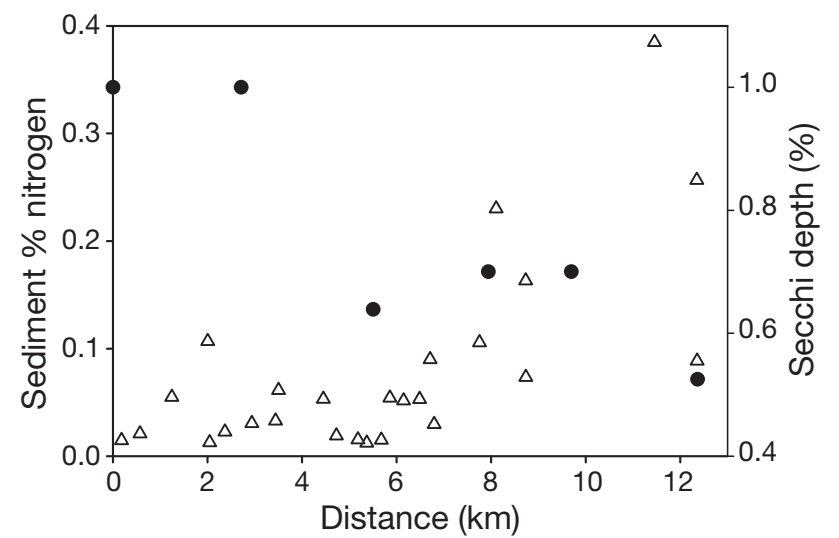

Fig. 4. Environmental parameters of study sites. Nitrogen content of sediment $(\Delta$, in percentage dry weight) and Secchi depth $(\bullet$, in percentage of the total water column) plotted along the natural light gradient. Sediment nitrogen values were obtained during the field survey. Secchi depths were recorded at the permanent monitoring stations (Stns 1 through 6 from left [0 km] to right [12 km])

Eelgrass productivity over the same distance decreased significantly from the inlet towards Quantuck Bay $(\mathrm{p}=0.004)$. Eelgrass productivity was $0.61 \pm$ $0.11 \mathrm{~cm}^{2}$ (short shoot: $\left.\mathrm{ss}\right)^{-1} \mathrm{~d}^{-1}$ at the inlet, and declined 3-fold to a low of $0.18 \pm 0.027 \mathrm{~cm}^{2} \mathrm{ss}^{-1} \mathrm{~d}^{-1}$ in Quantuck Bay (Fig. 3B). Productivity rates had highly significant negative correlations with the water column extinction coefficient ( $\left.\mathrm{p}=0.0004, \mathrm{r}^{2}=-0.983\right)$ and all chl a measurements (total chl a: $\mathrm{p}=0.001, \mathrm{r}^{2}=-0.970 ;>5 \mu \mathrm{m}$ chl $a: \mathrm{p}=0.015, \mathrm{r}^{2}=-0.899 ; 2$ to $5 \mu \mathrm{m}$ chl $a: \mathrm{p}=0.045$, $\mathrm{r}^{2}=-0.821 ;$ and $<2 \mu \mathrm{m}$ chl $\left.a: \mathrm{p}=0.002, \mathrm{r}^{2}=-0.965\right)$. Water column extinction coefficients were also significantly correlated with all chl a measurements, being most highly correlated with total chl a ( $\mathrm{p}=0.0027, \mathrm{r}^{2}=$ $0.957)$ and chl $a<2 \mu \mathrm{m}\left(\mathrm{p}=0.0061, \mathrm{r}^{2}=0.935\right)$.

\section{Shading vs. fertilization experiment}

Our experiments demonstrated that both nutrients and light levels can significantly impact the growth of eelgrass in eastern Shinnecock Bay. The total numbers of leaves per short shoot were significantly affected by both light level and nutrient treatment. Overall, the non-shaded treatments had significantly more leaves than shaded plots $(4.95 \pm 0.12$ vs. $3.41 \pm 0.16$ leaves $\mathrm{ss}^{-1}, \mathrm{p}<0.001$; Table 1). Within shaded treatments, the number of leaves was significantly higher in the presence of both hard clams and the fertilizer stake (3.99 \pm 0.17 and $3.67 \pm 0.18$ leaves $\mathrm{ss}^{-1}$, respectively) than in the control plot $\left(2.85 \pm 0.24\right.$ leaves $\left.\mathrm{ss}^{-1}, \mathrm{p}<0.001\right)$. Adding fertilizer to non-shaded plots also significantly increased leaf number $(\mathrm{p}=0.034)$ (Fig. 5A). There was a significant interaction between the light and nutrient treatments for the number of leaves per short shoot (Table 1).

Shading had a significant negative impact on both total leaf area and leaf productivity. Total leaf area was reduced in shaded plots $\left(33.9 \pm 2.79 \mathrm{~cm}^{2} \mathrm{ss}^{-1}\right)$ when compared to non-shaded plots $\left(48.2 \pm 2.70 \mathrm{~cm}^{2} \mathrm{ss}^{-1}, \mathrm{p}<\right.$ 0.001; Table 1). In the shaded plots, both the addition of hard clams and fertilizer stakes yielded leaf areas $\left(41.4 \pm 4.05\right.$ and $40.0 \pm 5.01 \mathrm{~cm}^{2} \mathrm{ss}^{-1}$, respectively) which were significantly greater ( $p=0.02$ for both) than in the control plots $\left(20.4 \pm 1.84 \mathrm{~cm}^{2} \mathrm{ss}^{-1}\right.$; Fig. 5B). Leaf productivity showed a similar trend, being significantly reduced in shaded plots $\left(1.03 \pm 0.09 \mathrm{~cm}^{2} \mathrm{ss}^{-1}\right.$ $\mathrm{d}^{-1}$; Table 1) compared to non-shaded plots (1.24 \pm $\left.0.08 \mathrm{~cm}^{2} \mathrm{ss}^{-1} \mathrm{~d}^{-1}, \mathrm{p}=0.014\right)$. Shaded control plots grew significantly slower $\left(0.564 \pm 0.057 \mathrm{~cm}^{2} \mathrm{ss}^{-1} \mathrm{~d}^{-1}\right)$ than shaded hard clam plots $\left(1.20 \pm 0.11 \mathrm{~cm}^{2} \mathrm{ss}^{-1} \mathrm{~d}^{-1}, \mathrm{p}<\right.$ $0.001)$ and fertilizer plots $\left(1.32 \pm 0.14 \mathrm{~cm}^{2} \mathrm{ss}^{-1} \mathrm{~d}^{-1}, \mathrm{p}<\right.$ 0.001; Fig. 5C). The addition of fertilizer and hard clams also significantly increased production in unshaded treatments. Unshaded clam plots $(1.36 \pm 0.10$ $\left.\mathrm{cm}^{2} \mathrm{ss}^{-1} \mathrm{~d}^{-1}, \mathrm{p}=0.002\right)$ and fertilizer plots $(1.53 \pm 0.16$ $\left.\mathrm{cm}^{2} \mathrm{ss}^{-1} \mathrm{~d}^{-1}, \mathrm{p}<0.001\right)$ experienced significantly higher productivity relative to unshaded control plots $(0.837 \pm$ $0.04 \mathrm{~cm}^{2} \mathrm{ss}^{-1} \mathrm{~d}^{-1}$; Fig. 5C).

Finally, leaf $\mathrm{N}$ levels were significantly affected by the presence of hard clams, fertilizer stakes, and light levels (Table 1). While leaves from the fertilizer stake treatment had the highest $\mathrm{N}$ content by weight $(1.53 \pm$ $0.04 \%, \mathrm{p}<0.001)$, the clam-treatment leaves also had a significantly higher $\mathrm{N}$ content $(1.42 \pm 0.03 \%, \mathrm{p}=$ $0.013)$ than the control $(1.32 \pm 0.03 \%$; Fig. 5D). Shading had a significant effect on nutrients, with nonshaded plots having higher nutrient contents than shaded plots $(1.48 \pm 0.03 \%$ vs. $1.38 \pm 0.03 \%, p=0.017)$. However, shaded fertilizer $(1.46 \pm 0.05 \% ; p=0.001)$ and shaded clam plots $(1.42 \pm 0.05 \% ; \mathrm{p}=0.014)$ had significantly elevated $\mathrm{N}$ levels relative to shaded control plots $(1.25 \pm 0.02 \%)$.

\section{DISCUSSION}

This study demonstrated that both light and nutrients can limit the productivity of Zostera marina within Long Island's south shore estuaries. Increasing phytoplankton densities across the longitudinal extent of Shinnecock Bay caused decreasing light levels and, in turn, decreased eelgrass productivity (Fig. 3). While artificially lowering light levels also decreased $Z$. marina production, nutrient enrichment of sediments in eastern Shinnecock Bay with fertilizer or hard clams yielded enhanced leaf numbers, areal productivity, and $\mathrm{N}$ content of leaf tissue of the eelgrass. Together, these results provide a refined understanding of the 
Table 1. Two-way ANOVA for the response variables of Zostera marina from the field manipulation experiments. Light refers to light level (ambient or shaded) and Treatment refers to nutrient level (control, clam or fertilizer). ss (as unit): short shoot

\begin{tabular}{|c|c|c|c|c|c|}
\hline & df & SS & MS & $F$ & $\mathrm{p}$ \\
\hline \multicolumn{6}{|c|}{ Short Shoot Density (ss m ${ }^{-2}$ ) } \\
\hline Light & 1 & 181060.267 & 181060.267 & 4.086 & 0.048 \\
\hline Treatment & 2 & 81467.733 & 40733.867 & 0.919 & 0.405 \\
\hline Light $\times$ Treatment & 2 & 180334.933 & 90167.467 & 2.035 & 0.141 \\
\hline Residual & 54 & 2393036.8 & 44315.496 & & \\
\hline Total & 59 & 2835899.733 & 48066.097 & & \\
\hline \multicolumn{6}{|l|}{ Leaf mass $\left(\mathrm{mg} \mathrm{ss}^{-1}\right)$} \\
\hline Light & 1 & 576.402 & 576.402 & 0.112 & 0.739 \\
\hline Treatment & 2 & 17673.699 & 8836.85 & 1.718 & 0.189 \\
\hline Light $\times$ Treatment & 2 & 27293.108 & 13646.554 & 2.653 & 0.08 \\
\hline Residual & 53 & 272636.635 & 5144.087 & & \\
\hline Total & 58 & 319598.507 & 5510.319 & & \\
\hline \multicolumn{6}{|c|}{ Plastochrone interval (d) } \\
\hline Light & 1 & 43.555 & 43.555 & 5.122 & 0.028 \\
\hline Treatment & 2 & 53.736 & 26.868 & 3.159 & 0.051 \\
\hline Light $\times$ Treatment & 2 & 2.935 & 1.468 & 0.173 & 0.842 \\
\hline Residual & 53 & 450.726 & 8.504 & & \\
\hline Total & 58 & 551.792 & 9.514 & & \\
\hline \multicolumn{6}{|l|}{ No. of leaves $\mathrm{ss}^{-1}$} \\
\hline Light & 1 & 34.949 & 34.949 & 93.902 & $<0.001$ \\
\hline Treatment & 2 & 10.531 & 5.265 & 14.148 & $<0.001$ \\
\hline Light $\times$ Treatment & 2 & 2.605 & 1.302 & 3.5 & 0.037 \\
\hline Residual & 53 & 19.726 & 0.372 & & \\
\hline Total & 58 & 68.001 & 1.172 & & \\
\hline \multicolumn{6}{|l|}{ Leaf length (mm) } \\
\hline Light & 1 & 25.849 & 25.849 & 0.0137 & 0.907 \\
\hline Treatment & 2 & 2226.684 & 1113.342 & 0.591 & 0.557 \\
\hline Light $\times$ Treatment & 2 & 12984.189 & 6492.094 & 3.447 & 0.039 \\
\hline Residual & 53 & 99834.013 & 1883.661 & & \\
\hline Total & 58 & 115126.938 & 1984.947 & & \\
\hline \multicolumn{6}{|l|}{ Leaf width (mm) } \\
\hline Light & 1 & 0.111 & 0.111 & 0.874 & 0.354 \\
\hline Treatment & 2 & 1.634 & 0.817 & 6.43 & 0.003 \\
\hline Light $\times$ Treatment & 2 & 0.234 & 0.117 & 0.92 & 0.405 \\
\hline Residual & 53 & 6.733 & 0.127 & & \\
\hline Total & 58 & 8.722 & 0.15 & & \\
\hline \multicolumn{6}{|l|}{ Leaf area $\left(\mathrm{cm}^{2} \mathrm{ss}^{-1}\right)$} \\
\hline Light & 1 & 3016.55 & 3016.55 & 15.99 & $<0.001$ \\
\hline Treatment & 2 & 2014.962 & 1007.481 & 5.341 & 0.008 \\
\hline Light $\times$ Treatment & 2 & 848.985 & 424.492 & 2.25 & 0.115 \\
\hline Residual & 53 & 9998.395 & 188.649 & & \\
\hline Total & 58 & 15902.268 & 274.177 & & \\
\hline \multicolumn{6}{|c|}{ Productivity $\left(\mathrm{cm}^{2} \mathrm{ss}^{-1} \mathrm{~d}^{-1}\right)$} \\
\hline Light & 1 & 0.655 & 0.655 & 6.446 & 0.014 \\
\hline Treatment & 2 & 5.81 & 2.905 & 28.602 & $<0.001$ \\
\hline Light $\times$ Treatment & 2 & 0.0327 & 0.0164 & 0.161 & 0.852 \\
\hline Residual & 53 & 5.383 & 0.102 & & \\
\hline Total & 58 & 11.865 & 0.205 & & \\
\hline \multicolumn{6}{|c|}{ Leaf tissue nitrogen content ( $\%$ dry weight) } \\
\hline Light & 1 & 0.114 & 0.114 & 6.081 & 0.017 \\
\hline Treatment & 2 & 0.391 & 0.196 & 10.45 & $<0.001$ \\
\hline Light $\times$ Treatment & 2 & 0.0458 & 0.0229 & 1.223 & 0.303 \\
\hline Residual & 48 & 0.899 & 0.0187 & & \\
\hline Total & 53 & 1.46 & 0.0275 & & \\
\hline
\end{tabular}

manner in which light and nutrients can interact to co-limit eelgrass communities in temperate estuaries and demonstrate how hard clam populations can facilitate enhanced eelgrass productivity.

Although there is no historic data for Zostera marina within the study area, eelgrass once covered between 40 and $60 \%$ of other coastal lagoons in LISSE. Surveys from this study found seagrass present at only $14 \%$ of the sites in Shinnecock and Quantuck Bays. One factor contributing to eelgrass decline within this system has been light limitation (Cosper et al. 1987). A strong natural light gradient existed across the estuary, with highest light at the inlet $\left(K_{d}=0.88\right)$ and light levels decreasing with distance from the ocean inlet (Quantuck Bay $K_{d}=2.05$ ). This light gradient showed strong negative correlation with eelgrass growth, which was over $0.6 \mathrm{~cm}^{2}$ shoot $^{-1} \mathrm{~d}^{-1}$ at the inlet, but was reduced significantly to $0.18 \mathrm{~cm}^{2}$ of new growth shoot ${ }^{-1} \mathrm{~d}^{-1}$ at the most distant station ( $p=0.004$; Fig 3$)$. Similarly, artificial shading used for our in situ experiment significantly decreased leaf number, total leaf area and leaf areal production by 31,29 , and $17 \%$, respectively, compared to ambient light $(\mathrm{p}=0.001,0.001$, and 0.014, respectively; Fig 5).

In many estuaries, eutrophication can promote light limitation, as increasing nutrient loads result in phytoplankton blooms which can 'shade out' seagrass beds (Dennison et al. 1989, Valiela et al. 1992, Short \& Burdick 1996, Duarte 2002, Green \& Short 2003, Hauxwell et al. 2006). This process likely occurs in the western portions of Shinnecock Bay as well as Quantuck Bay, where the highest phytoplankton density was observed: mid-summer chl a levels reached a maximum of $30 \mathrm{\mu g} \mathrm{l}^{-1}$, with a mean value of $18 \pm 11 \mu \mathrm{g} \mathrm{l}^{-1}$. Conversely at the inlet, the mean chl a value was $0.83 \pm 0.35 \mu \mathrm{g} \mathrm{l}^{-1}$. In addition, sediment $\mathrm{N}$ concentrations in the shaded, western extent of Shinnecock Bay $(0.19 \pm 0.097 \% \mathrm{~N})$ were over 4 times 

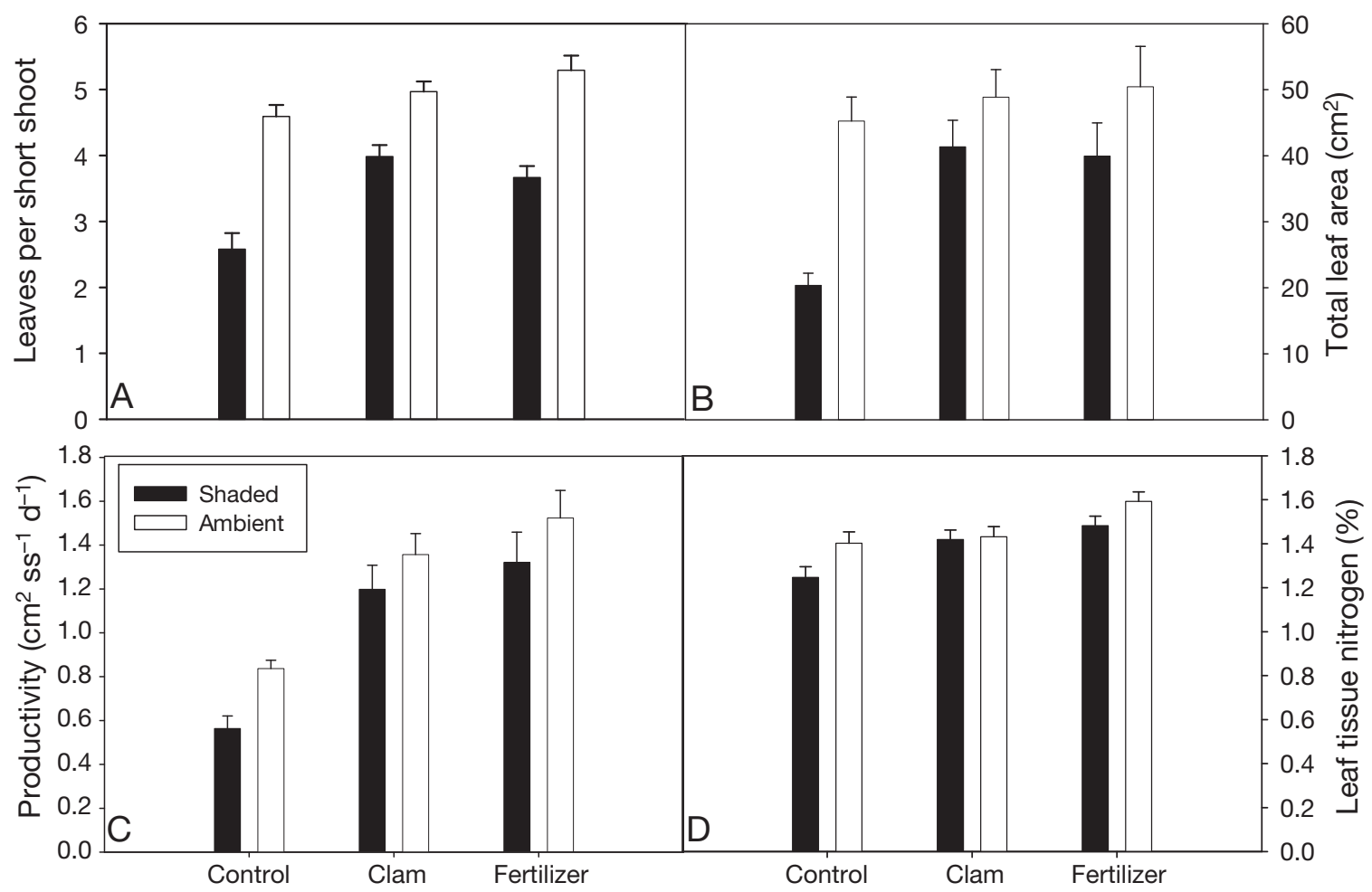

Fig. 5. Zostera marina. Response variables (mean + SE) for different nutrient treatments and ambient and shaded light conditions. (A) total number of leaves per short shoot (ss), (B) total leaf area per short shoot, (C) areal productivity per short shoot, and (D) leaf tissue nitrogen

greater than concentrations close to the inlet $(0.038 \pm$ $0.037 \% \mathrm{~N}_{i}$ Fig. 4). The trends in light and chl a observed across Shinnecock Bay are consistent with long-term data collected by SCDHS (1976 to 2005), and support the hypothesis that light, but not $\mathrm{N}$, limits eelgrass production in Quantuck Bay and western Shinnecock Bay.

While light may be limiting in the western portions of Shinnecock Bay, our experiments indicated that nutrients can limit Zostera marina growth in the eastern portion of the bay where light levels are high but sediment $\mathrm{N}$ content is low (Fig. 4). In situ experimental results indicated that, even under ambient light conditions, the addition of nutrients increased eelgrass growth, as fertilized plots had significantly higher numbers of leaves $(\mathrm{p}=0.034)$ that were wider $(\mathrm{p}=$ $0.008)$, and grew significantly faster $(p<0.001)$. The presence of hard clams in ambient light treatments also significantly increased eelgrass growth $(\mathrm{p}=$ 0.002). Prior studies have shown that seagrass can be limited by the presence or absence of nutrients, which can lead to reduced leaf productivity and biomass (Hemminga et al. 1999, Hemminga \& Duarte 2000). Seagrasses have a mean leaf tissue $\mathrm{N}$ concentration of $1.9 \pm 0.7 \%$, and concentrations below this value may indicate N limitation (Duarte 1992). Seagrass in our un- fertilized plots contained $1.32 \pm 0.03 \% \mathrm{~N}$, while plots enriched with hard clams had $1.42 \pm 0.03 \% \mathrm{~N}$ and plots with commercial fertilizer had $1.53 \pm 0.04 \% \mathrm{~N}$, suggesting these eelgrasses were N-limited. Thus, it appears that a lack of sediment $\mathrm{N}$ in the clear waters near the inlet of eastern Shinnecock Bay may prevent eelgrass from attaining maximal growth. Previous studies have also shown that eelgrass increases leaf chlorophyll content in response to light reduction (Dennison \& Alberte 1986, Hemminga \& Duarte 2000), which increases the requirement for nitrogen. Therefore, the influence of both the hard clam and the fertilizer significantly elevating the leaf tissue $\mathrm{N}$ content above control plots in the shaded treatments indicates a potential response of the eelgrass to the light limitation.

Hard clams have the ability to facilitate eelgrass growth. Many bivalves can efficiently filter large quantities of water, decrease phytoplankton levels in the water column (Officer et al. 1982), reduce light attenuation (Moore et al. 1996, Newell \& Koch 2004), and subsequently cause significant increases in the growth of seagrass (Wall et al. 2008). However, our study focused on the ability of hard clams to increase nutrient availability for eelgrass. Compared to control plots, eelgrass production in both ambient light and artificially shaded treatments was significantly higher 
in plots with hard clams (Fig. $5 \mathrm{C}, \mathrm{p}<0.05$ ). Eelgrass on plots with hard clams also had higher $\mathrm{N}$ concentrations in their tissues (Fig. 5D, p < 0.05). These results were nearly identical to those obtained with the fertilizer stakes (Fig. 5C-D, p < 0.05). The increase in leaf tissue $\mathrm{N}$ content indicates that there was an increase in sediment $\mathrm{N}$ concentrations, which could be achieved by hard clams in 2 ways: nutrient-rich biodeposition or sediment reworking. Since filterfeeders are a major facilitator of benthic-pelagic coupling by bringing water column production to the benthos where $\mathrm{N}$-enriched biodeposits help fuel benthic production (Kitchell et al. 1979, Doering et al. 1987, Dame 1996, Grizzle et al. 2001), it is possible that nutrient additions via feces of the hard clams increased the eelgrass productivity and leaf tissue $\mathrm{N}$ content. Alternatively, burrowing clams may have changed the redox potential of the sediments and increased nutrient solubility or regeneration (Kristensen \& Blackburn 1987, Aller 1994). To our knowledge, our experimental results give the first demonstration of hard clams facilitating eelgrass growth via increases in nutrient availability, although similar interactions have been well-documented in other bivalve-vegetation interactions (Bertness \& Leonard 1997, Reusch \& Williams 1998, Peterson \& Heck 1999, 2001). It is important to note that we did not find any relationship between the presence of clams and sediment nutrient conditions in our field survey. However, natural hard clam densities in the system were much lower than those used for the in situ experiment, and the strong east-west gradient (Fig. 4) in sediment nitrogen levels may have overwhelmed any signal imparted by the presence of hard clams.

These results demonstrate the existence of positive interactions between hard clams and eelgrass. Seagrass species are often considered to be foundation species in submerged marine habitats for the variety of services they provide, such as protection from predation, sediment stabilization and oxygenation, and the dampening of currents. The results of this study support this concept of eelgrass as a foundation species in LISSE: there were approximately double the numbers of hard clams within eelgrass beds $\left(1.07 \mathrm{~m}^{-2}\right)$ compared to outside $\left(0.62 \mathrm{~m}^{-2}\right)$. Further, $67 \%$ of sites surveyed in Shinnecock Bay with eelgrass possessed clams. While our experimental results indicate that clams within these eelgrass beds may enhance eelgrass growth, it is important to note that natural densities are far below the experimental treatment densities of $16 \mathrm{~m}^{-2}$. While it is possible that the differences in hard clam density within and outside of eelgrass can be due to difficulty of harvesting clams within eelgrass, the complex habitat structure of eelgrass may also protect Mercenaria mercenaria from predation (Peterson
1982) and increase growth (Irlandi \& Peterson 1991, Irlandi 1996). While positive interactions are often thought to be more important in alleviating abiotic stress (Bertness \& Leonard 1997, Callaway \& Walker 1997, Bruno et al. 2003), it can be argued that finding refuge from a biotic stress can also be considered a positive interaction.

Results from the in situ experiment show that eelgrass can benefit from the presence of hard clams. Clams are capable of broadening the range of physical conditions within which eelgrass can survive by improving the conditions of a habitat, either through increasing nutrients as shown in this study, or by increasing light penetration (Wall et al. 2008). When the species benefitting from the foundation species facilitate the expansion of the niche of the foundation species in turn, this can make an ecosystem more stable (Stachowicz 2001). This kind of positive feedback also supports the concept of whole community mutualism (Bracken et al. 2007), where associated species facilitate the growth/persistence of the foundation species. A similar process has been described for a turf macroalgae, another habitat-forming SAV (Bracken 2004, Bracken et al. 2007). In addition to increasing the sediment nutrient pool and nutrient availability, hard clams can also potentially facilitate eelgrass growth by filtering the water column to alleviate light stress, as well as increase sediment oxygen supply through burrowing activity.

This study demonstrates that the overgrowth of phytoplankton leads to strong light limitation of eelgrass in western Shinnecock Bay, as is the case in many estuaries (Dennison et al. 1989, 1993). However, as is also the case in many other systems, there is a strong gradient in light and sediment $\mathrm{N}$ concentrations across the complete longitudinal gradient of the estuary, where the lowest light levels often have the highest nutrient levels (Fig. 4). While our experimental results suggest that increasing nutrients can increase eelgrass growth under low light conditions, there must be a minimal light level for eelgrass growth, and prolonged low light conditions (as in the western portions of the study area) may negate any positive nutrient influence. As such, simply restricting estuarine nutrient loads to reduce pelagic algal standing stocks, increase light levels, and increase eelgrass growth in Shinnecock Bay might also restrict eelgrass populations in regions with higher light levels and nutrient concentrations that are already low (Fig. 4). Our results suggest a management approach in which enhanced filter-feeding bivalve populations, such as hard clams, might increase both light and nutrient availability and enhance eelgrass growth. The current study, combined with the results of Wall et al. (2008), suggests that hard clam densities of 16 ind. $\mathrm{m}^{-2}$ would 
enhance sediment nutrient concentrations and increase light availability to levels which increase eelgrass population growth. While this density is higher than current abundances ( 1 to 5 ind. $\mathrm{m}^{-2}$; Weiss et al. 2007), it is lower than historical densities (Greene 1978, Buckner 1984). Such enhancement of filter feeder stocks is most likely to achieve success in shallow and more pristine coastal lagoons such as LISSE (mean depth $1.2 \mathrm{~m}$; Gobler et al. 2005), where the influence of the benthos on the water column is maximal. Deeper and/or more eutrophic estuaries, however, are more likely to require an extensive bivalve restoration effort coupled with nutrient mitigation to increase water clarity and seagrass growth.

Acknowledgements. We thank the individuals who assisted this project, including M. Weiss, P. Curran, S. Petrochic, R. Maloney, C. Mulligan, and R. Gutierrez. We also thank C. Wall for his comments and the staff of the marine station of the former Southampton College, for boat and equipment maintenance. This project was funded by New York Sea Grant, the Stony Brook - Southampton Coastal and Estuarine Research Project (SCERP), and the Evan Frankel Foundation. This project is contribution no. 1375 of the Marine Sciences Research Center at Stony Brook University.

\section{LITERATURE CITED}

Aller RC (1994) Bioturbation and remineralzation of sedimentary organic matter: effects of redox oscillation. Chem Geol 114:331-345

Ambrose WG Jr, Peterson CH, Summerson HC, Lin J (1992) Experimental tests of factors affecting recruitment of bay scallops (Argopecten irradians) to spat collectors. Aquaculture 108:67-86

Atkinson MJ, Smith SV (1983) C:N:P ratios of benthic marine plants. Limnol Oceanogr 28:568-574

Backman TW, Barilotti DC (1976) Irradiance reduction: effects on standing crops of the eelgrass Zostera marina in a coastal lagoon. Mar Biol 34:33-40

Berner RA (1971) Principles of chemical sedimentology. McGraw-Hill, New York

Bertness MD, Leonard GH (1997) The role of positive interactions in communities: lessons from intertidal habitats. Ecology 78:1976-1989

Bologna PAX, Heck KLJ (2000) Impacts of seagrass habitat architecture on bivalve settlement. Estuaries 23:449-457

Bracken M (2004) Invertebrate-mediated nutrient loading increases growth of an intertidal macroalga. J Phycol 40:1032-1041

Bracken M, Gonzalez-Dorantes C, Stachowicz J (2007) Whole-community mutualism: associated invertebrates facilitate a dominant habitat forming seaweed. Ecology 88:2211-2219

Braun-Blanquet J (1972) Plant sociology: the study of plant communities. Hafner Publishing Company, New York

Bruno JF, Stachowicz JJ, Bertness MD (2003) Inclusion of facilitation into ecological theory. Trends Ecol Evol 18:119-125

Buckner S (1984) Aspects of the population dynamics of the hard clam, Mercenaria mercenaria, in Great South Bay, NY. Stony Brook University, New York
Callaway RM, Walker LR (1997) Competition and facilitation: a synthetic approach to interactions in plant communitites. Ecology 78:1958-1965

Cerrato RM, Caron DA, Lonsdale DJ, Rose JM, Schaffner RA (2004) Effect of the northern quahog Mercenaria mercenaria on the development of blooms of the brown tide alga Aureococcus anophagefferens. Mar Ecol Prog Ser 281: 93-108

Cosper E, Dennison W, Carpenter E, Bricelj V and others (1987) Recurrent and persistent brown tide blooms perturb coastal marine ecosystems. Estuaries 10:284-290

Dame RF (1996) Ecology of marine bivalves: an ecosystem approach. CRC Press, Boca Raton, FL

Dennison WC, Alberte RS (1986) Photoadaptation and growth of Zostera marina L. (eelgrass) transplants along a depth gradient. J Exp Mar Biol Ecol 98:265-282

Dennison WC, Marshall GJ, Wigand C (1989) Effect of ‘brown tide' shading on eelgrass (Zostera marina L.) distributions. In: Cosper EM, Bricelj VM, Carpenter EJ (eds) Novel phytoplankton blooms: causes and impacts of recurrent brown tides and other unusual blooms. Springer-Verlag, Berlin, p $675-692$

> Dennison WC, Orth RJ, Moore KA, Stevenson JC and others (1993) Assessing water quality with submersed aquatic vegetation. BioScience 43:86-94

Doering PH, Kelly J, Oviatt CA, Sowers T (1987) Effect of the hard clam Mercenaria mercenaria on benthic fluxes of inorganic nutrients and gases. Mar Biol 94:377-383

Duarte CM (1992) Nutrient concentrations of aquatic plants: patterns across species. Limnol Oceanogr 37:882-889

> Duarte CM (2002) The future of seagrass meadows. Environ Conserv 29:192-206

Fourqurean JW, Zieman JC, Powell GVN (1992) Relationships between porewater nutrients and seagrasses in a subtropical carbonate environment. Mar Biol 114:57-65

> Fourqurean JW, Willsie A, Rose CD, Rutten LM (2001) Spatial and temporal pattern in seagrass community composition and productivity in south Florida. Mar Biol 138:341-354

Gobler CJ, Lonsdale DJ, Boyer GL (2005) A review of the causes, effects, and potential management of harmful brown tide blooms caused by Aureococcus anophagefferens (Hargraves et Sieburth). Estuaries 28:726-749

Green EP, Short FT (2003) World atlas of seagrasses. University of California Press, Berkeley, CA

Greene GT (1978) Population structure, growth and mortality of hard clams at selected locations in Great South Bay, New York. MSc thesis, State University of New York, Stony Brook

Grizzle R, Bricelj V, Shumway S (2001) Physiological ecology of Mercenaria mercenaria. In: Krauter J, Castagna M (eds) Biology of the hard clam. Elsevier, New York

Hauxwell J, Cebrian J, Furlong C, Valiela I (2001) Macroalgal canopies contribute to eelgrass (Zostera marina) decline in temperate estuarine ecosystems. Ecology 82:1007-1022

> Hauxwell J, Cebrian J, Valiela I (2006) Light dependence of Zostera marina annual growth dynamics in estuaries subject to different degrees of eutrophication. Aquat Bot $84: 17-25$

> Heck KL, Wetstone GS (1977) Habitat complexity and invertebrate species richness and abundance in tropical seagrass meadows. J Biogeogr 4:135-142

Hemminga MA, Duarte CM (2000) Seagrass ecology. Cambridge University Press, Cambridge

> Hemminga MA, Marbà N, Stapel J (1999) Leaf nutrient resorption, leaf lifespan and the retention of nutrients in seagrass systems. Aquat Bot 65:141-158

Holmer M, Laursen L (2002) Effects of shading of Zostera 
marina (eelgrass) on sulfur cycling in sediments with contrasting organic matter and sulfide pools. J Exp Mar Biol Ecol 270:25-37

Irlandi EA (1994) Large- and small-scale effects of habitat structure on rates of predation: how percent cover of seagrass affects rates of predation and siphon-nipping on an infaunal bivalve. Oecologia 98:176-183

Irlandi EA (1996) The effects of seagrass patch size and energy regime on growth of a suspension-feeding bivalve. J Mar Res 54:161-185

Irlandi EA (1997) Seagrass patch size and survivorship of an infaunal bivalve. Oikos 78:511-518

Irlandi EA, Mehlich ME (1996) The effect of tissue cropping and disturbance by browsing fishes on growth of two species of suspension-feeding bivalves. J Exp Mar Biol Ecol 197:279-293

Irlandi EA, Peterson CH (1991) Modification of animal habitat by large plants: mechanisms by which seagrasses influence clam growth. Oecologia 87:307-318

Kitchell J, O'Neill R, Webb D, Gallep G, Bartell S, Koonce J, Ausmus B (1979) Consumer regulation of nutrient cycling. BioScience 29:28-34

Kristensen E, Blackburn TH (1987) The fate of organic carbon and nitrogen in experimental marine sediment systems: influence of bioturbation and anoxia. J Mar Res 45: 231-257

Moore KA, Neckles HA, Orth RJ (1996) Zostera marina (eelgrass) growth and survival along a gradient of nutrients and turbidity in the lower Chesapeake Bay. Mar Ecol Prog Ser 142:247-259

Morel A (1987) Chlorophyll-specific scattering coefficient of phytoplankton. A simplified theoretical approach. DeepSea Res 34:1093-1105

Newell RIE, Koch EW (2004) Modeling seagrass density and distribution in response to changes in turbidity stemming from bivalve filtration and seagrass sediment stabilization. Estuaries 27:793-806

Newell RIE, Cornwell JC, Owens MS (2002) Influence of simulated bivalve biodeposition and microphytobenthos on sediment nitrogen dynamics: a laboratory study. Limnol Oceanogr 47:1367-1379

Officer CB, Smayda TJ, Mann R (1982) Benthic filter feeding: a natural eutrophication control. Mar Ecol Prog Ser 9: 203-210

Parsons TR, Maita Y, Lalli CM (1984) A manual of chemical and biological methods for seawater analysis. Pergamon Press, New York

> Peralta G, Bouma TJ, van Soelen J, Perez-Llorens JL, Hernandez I (2003) On the use of sediment fertilization for seagrass restoration: a mesocosm study on Zostera marina L. Aquat Bot 75:95-110

Peterson CH (1982) Clam predation by whelks (Busycon spp.): experimental tests of the importance of prey size,

Editorial responsibility: Kenneth Heck, Dauphin Island, Alabama, USA prey density, and seagrass cover. Mar Biol 66:159-170

Peterson BJ, Heck KL Jr (1999) The potential for suspension feeding bivalves to increase seagrass productivity. J Exp Mar Biol Ecol 240:37-52

> Peterson BJ, Heck KL Jr (2001) Positive interactions between suspension-feeding bivalves and seagrass - a facultative mutualism. Mar Ecol Prog Ser 213:143-155

Reusch TBH, Williams SL (1998) Variable responses of native eelgrass Zostera marina to a non-indigenous bivalve Musculista senhousia. Oecologia 113:428-442

Ryther JH, Dunstan WM (1971) Nitrogen, phosphorus, and eutrophication in the coastal marine environment. Science 171:1008-1013

> Short FT, Burdick DM (1996) Quantifying eelgrass habitat loss in relation to housing development and nitrogen loading in Waquoit Bay, Massachusetts. Estuaries 19:730-739

Smaal AC, Prins TC (1993) The uptake of organic matter and the release of inorganic nutrients by bivalve suspension feeder beds. In: Dame RF (ed) Bivalve filter feeders in estuarine and coastal ecosystem processes. SpringerVerlag, Berlin, p 271-298

- Stachowicz JJ (2001) Mutualism, facilitation, and the structure of ecological communities. BioScience 51:235-246

Suffolk County Department of Health Services (SCDHS) (1976-2005) Annual report on water quality in Suffolk County's coastal waters. Office of Ecology, New York

> Valiela I, Foreman K, Hersh ML, Costa D and others (1992) Couplings of watersheds and coastal waters: sources and consequences of nutrient enrichment in Waquoit Bay, Massachusettes. Estuaries 15:443-457

Valiela I, Collins G, Kremer J, Lajitha K and others (1997) Nitrogen loading from coastal watersheds to receiving estuaries: new methods and applications. Ecol Appl 7: 358-380

Wall CC, Peterson BJ, Gobler CJ (2008) Facilitation of seagrass Zostera marina productivity by suspension-feeding bivalves. Mar Ecol Prog Ser 357:165-174

Watson DF (1992) Contouring: a guide to the analysis and display of spatial data, Vol 10. Pergamon Press, New York

Weiss MB, Curran PB, Peterson BJ, Gobler CJ (2007) The influence of plankton composition and water quality on hard clam (Mercenaria mercenaria L.) populations across Long Island's south shore lagoon estuaries (New York, USA). J Exp Mar Biol Ecol 345:12-25

Wilson R, Wong K, Carter H (1991) Aspects of circulation and exchange in Great South Bay. In: Shubel J, Bell T, Carter $\mathrm{H}$ (eds) The Great South Bay. State University of New York Press, Albany, NY

Zar JH (1996) Biostatistical analysis. Prentice-Hall, Upper Saddle River, NJ

Zieman JC (1974) Methods for the study of the growth and production of turtle grass, Thalassia testudinum König. Aquaculture 4:139-143

Submitted: November 5, 2007; Accepted: May 30, 2008 Proofs received from author(s): September 21, 2008 